\title{
Paweł Boike
}

Uniwersytet Mikołaja Kopernika, Toruń

pawboike1998@gmail.com

ORCID: https://orcid.org/0000-0003-0789-0897

\section{Państwo prawa w obiektywie społecznego nauczania Kościoła katolickiego. Zarys problematyki}

\author{
http://dx.doi.org/10.12775/SIT.2021.001
}

Autentyczna demokracja jest możliwa tylko $w$ państwie prawnym i $w$ oparciu o poprawna koncepcję osoby ludzkiej*.

\section{Wprowadzenie}

Idea praworządności, a wraz z nią koncepcja państwa prawa odgrywa istotną rolę w dyskursie naukowym. Nie dziwi zatem fakt, że badacze poświęcili im tak wiele miejsca, przyjmując perspektywę takich dziedzin jak: dogmatyka prawa konstytucyjnego, filozofia państwa i prawa, historia doktryn polityczno-prawnych, historia prawa, a także europeistyka oraz filozofia polityki ${ }^{1}$. Idea rządów

* Jan Paweł II, Encyklika „Centesimus annus”, Rzym 1991, nr 46, http:// www.vatican.va/content/john-paul-ii/pl/encyclicals/documents/hf_jp-ii_enc_ 01051991_centesimus-annus.html (dostęp: 23.08.2020 r.).

${ }^{1}$ Przykładowe monografie: J. Nowacki, Rzady prawa: dwa problemy, Katowice 1995; B. Tamanaha, On the rule of law. History, Politics, Theory, Cambridge 
prawa należy do takich konstruktów myślowych, które nie dają się zamknąć w prostej definicji. Za Zbigniewem Kmieciakiem zostaną tu przywołane cztery zespoły zasad, stanowiących swoiste desygnaty praworządności:

1) rząd, jego urzędnicy i przedstawiciele, jak też osoby prywatne w całości podlegają prawu;

2) ustawy są jasne i ścisłe oraz podane do publicznej wiadomości; chronią one prawa podstawowe, włączając w to bezpieczeństwo osób i własności, a ponadto stosowane są równo wobec wszystkich;

3) procesy tworzenia i wykonywania prawa oraz sprawowania administracji spełniają wymagania dostępności, odpowiedniości i skuteczności;

4) sprawiedliwość wymierzana jest bez zwłoki przez kompetentnych, niezależnych i zachowujących właściwą postawę etyczną funkcjonariuszy, powołanych w wystarczającej liczbie oraz

2004; I. Wróblewska, Zasada państwa prawnego $w$ orzecznictwie Trybunału Konstytucyjnego RP, Toruń 2010; T. Biernat, Władze publiczne $w$ demokratycznym państwie prawa, Kraków 2014; T. Pietrzykowski, Ujarzmianie Lewiatana. Szkice o idei rządów prawa, Katowice 2014; Rządy prawa i europejska kultura prawna, red. A. Bator, J. Helios, W. Jedlecka, Wrocław 2014, https: / / www.google.com/search?client=firefoxbd\&q=rz\%C4\%85dy+prawa+a+eurpejsk a+kultura+prawna (dostęp: 18.08.2020 r.); Państwo demokratyczne, prawne i socjalne. Księga jubileuszowa dedykowana profesorowi Zbigniewowi Antoniemu Maciagowi. Tom 1, Studia konstytucyjne, red. M. Grzybowski, P. Tuleja, Kraków 2014; P. Gowder, Rule of Law in the Real World, Cambridge 2016; M. Taborowski, Mechanizmy ochrony praworzadności państw członkowskich $w$ prawie Unii Europejskiej. Studium przebudzenia systemu ponadnarodowego, Warszawa 2019. Przykładowe mniejsze opracowania: A. Dziadzio, Koncepcja państwa i prawa w XIX wieku - idea i rzeczywistość, „Czasopismo Prawno-Historyczne” 2005, nr 1 (57), s. 177-201; Z. Kmieciak, O pojęciu rząów prawa, „Państwo i Prawo” 2016, nr 9, s. 21-35; M. Krygier, The Rule of Law: Pasts, Presents, and Two Possible Futures, „Annual Review of Law and Social Science" 2016, nr 12, s. 199-229; J. Isensee, Demokratyczne państwo prawa i jego przyszłość, „Chrześcijaństwo - Świat - Polityka” 2017, nr 21, s. 9-24; A. Krzynówek-Arndt, Państwo prawa w klasycznej tradycji zachodniej i późnej nowoczesności $w$ kontekście sporów wokół klauzuli demokratycznego państwa prawnego, „Przegląd Sejmowy” 2018, nr 3 (146), s. 79-102. 
dysponujących adekwatnymi środkami, będących odbiciem charakteru zbiorowości ${ }^{2}$.

Clue idei zawiera się niewątpliwie w punkcie 1 , tj. w podległości rządzących (a nie tylko rządzonych) prawu. Punkt 2 można interpretować jako postulat zachowania wewnętrznej i zewnętrznej moralności tego prawa. Punkty 3 i 4 zaś odnoszą się do rzetelności procesu jego stanowienia i stosowania.

Cel i charakter niniejszego opracowania nie pozwalają na zarysowanie kształtowania się koncepcji rządów prawa na przestrzeni dziejów. Podkreślić jednak należy, iż zalążek idei praworządności tkwi w przekonaniu, że ponad wolą władców stoi prawo boskie bądź naturalne ${ }^{3}$. Istota rządów w granicach prawa sprowadza się jednak do ograniczenia władzy przez prawo nie tylko naturalne, ale też to stanowione przez lud. Nowoczesne rozumienie rządów prawa wyrosło przede wszystkim na gruncie nowożytnego kontraktualizmu (Samuel Rutherford, John Locke, Jean-Jacques Rousseau, Charles Louis de Secondat [Monteskiusz]) ${ }^{4}$. Teoria umowy społecznej znalazła swój wyraz w konstytucjonalizmie amerykańskim i francuskim, który suwerenem $\mathrm{w}$ miejsce monarchy uczynił lud. W rezultacie władzy wyznaczono prawne ramy - ograniczenia ${ }^{5}$. Historyczny rozwój koncepcji państwa prawa (niem. Rechtstaat) ewoluował od liberalnych postulatów uznania przez władzę publiczną poszczególnych wartości w relacji do obywateli (praworządność materialna) ku propozycjom mechanizmów ustrojowych i proceduralnych mających gwarantować ich urzeczywistnienie (praworządność formalna) ${ }^{6}$.

${ }^{2}$ Z. Kmieciak, O pojęciu, s. 25.

${ }^{3}$ T. Pietrzykowski, Ujarzmienie, s. 67.

${ }^{4}$ Por. J. Podczaszy, Koncepcja rzadów prawa a jej stosowanie $w$ Polsce, w: Rządy prawa i europejska, s. 30-32. Myśl tego pierwszego jest wyraźnie mniej znana od pozostałych. Ostatnio pojawiło się w polskiej literaturze ciekawe opracowanie, do którego warto odesłać: T. Tulejski, Samuela Rutherforda koncepcja genezy społeczeństwa, władzy i państwa, „Studia Prawno-Ekonomiczne” 2019, nr 112, s. 137-154.

${ }^{5}$ Zob. A. Tarnowska, Koncepcja nowoczesnego konstytucjonalizmu $w$ historii prawa, „Studia Iurdica Toruniensia” 2009, nr 5, s. 62-78.

${ }^{6}$ Zob. A. Dziadzio, Koncepcja państwa, s. 179-181. 
Celem niniejszego studium jest ustalenie relacji między współczesnym społecznym nauczaniem Kościoła a ideą praworządności rozumianą przede wszystkim przez pryzmat punktu 1 . Analizie poddane zostanie nauczanie papieży oraz II Soboru Watykańskiego. Do tej pory nikt w polskiej nauce nie postawił problemu w ten sposób ${ }^{7}$.

Odnotować tutaj należy, że misja nauczycielska Kościoła realizuje się w moralnych i profetycznych wypowiedziach, które odnoszą się czasami do problemów życia społecznego, gospodarczego i politycznego. Głosy te stanowią przedmiot dociekań i inspiracji dla dyscypliny noszącej nazwę „katolicka nauka społeczna” ${ }^{\text {. Nie- }}$ kiedy niektórymi aspektami społecznej nauki Kościoła zajmują się przedstawiciele swieckich dyscyplin, takich jak: prawo, ekonomia

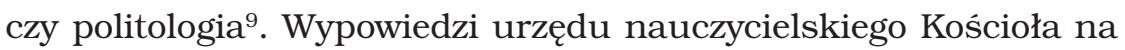

7 Choć dostępne są w języku polskim dotyczące tej tematyki eseje wybitnego niemieckiego konstytucjonalisty i filozofa prawa: E.W. Böckenförde, Wolność państwo - Kościół, tłum. P. Kaczorowski, Kraków 1994.

${ }^{8}$ Przykładowe ogólne opracowania przedmiotu: J. Majka, Katolicka nauka społeczna. Studium historyczno-doktrynalne, Rzym-Lublin 1987; K. Biliński, M. Żmuda, Nauka społeczna Kościoła katolickiego od Leona XIII do Jana Pawła II. Wybór tekstów źródłowych, Toruń 1997; H. Juros, Kościót - kultura Europa: katolicka nauka społeczna wobec wspótczesności, Lublin 1997; T. Herr, Wprowadzenie do katolickiej nauki społecznej, tłum. A. Mosurek, Kraków 1999; V. Possenti, Katolicka nauka społeczna wobec dziedzictwa oświecenia, tłum. Ł. Skuza, S. Pyszka, T. Żeleźnik, Kraków 2000; K. Chojnicka, Nauka społeczna Kościoła katolickiego (zarys historii), Kraków 2001; B. Sorge, Wykłady z katolickiej nauki społecznej. Od Ewangelii do cywilizacji miłości, tłum. M. Zaręba, Kraków 2001; D. Schwindt, Catholic Social Teaching: A New Synthesis (Rerum Novarum to Laudato Si'), McPherson 2015.

9 Tytułem przykładu - nauki prawne: M. Sadowski, Państwo $w$ doktrynie Leona XIII, Wrocław 2002; idem, Godność człowieka i dobro wspólne w papieskim nauczaniu społecznym (1878-2005), Wrocław 2010, http://www. bibliotekacyfrowa.pl/publication/28119 (dostęp: 18.08.2020 r.); M. Łuszczyńska, Katolicka nauka społeczna - doktryna per se czy per participationem?, „Studia Iurdica Lublinensia” 2012, nr 17, s. 89-102; P. Boike, Nowa redakcja katolickiego nauczania o karze śmierci - rewolucja czy drobna korekta?, „Dialogi Polityczne” 2019, nr 27, s. 43-54; nauki polityczne: D. Góra-Szopiński, Złoty środek. Kościót wobec wspótczesnych wizji państwa, Toruń 2007, idem, Katolicka nauka społeczna jako wyzwanie dla politologii, „Athenaeum” 2010, nr 24, s. 51-69; B. Szlachta, Wokół katolickiej myśli politycznej, Kraków 2008; A. Dylus, Polityka $w$ perspektywie etycznej i religijnej, Warszawa 2014; nauki 
tematy społeczne przyjmują najczęściej postać encyklik papieskich, ale bywają także inne formy przekazu. Trzeba zaznaczyć, że choć encyklika Leona XIII Rerum Novarum ${ }^{10}$ stanowi ważny dokument w historii społecznego nauczania Kościoła, to owo nauczanie jest tak stare jak samo chrześcijaństwo.

\section{Praworządność a społeczne nauczanie Kościoła katolickiego do poł. XX w.}

Fundament stojący u podstaw koncepcji rządów prawa, tj. przekonanie o istnieniu prawa naturalnego (względnie boskiego), któremu podlega władca, jest obecny od zarania chrześcijaństwa. Sięga on do judaizmu. Prawo mojżeszowe stanowiło wyraźnie, że król Izraela ma przestrzegać prawa (Pwt 17,14-20). Chociaż chodzi o prawo proweniencji nadprzyrodzonej, to jednocześnie o prawo spisane i w wielu miejscach bardzo szczegółowe ${ }^{11}$. Warto zauważyć, że wpływowy kościelny autorytet, Tomasz z Akwinu, w czasach powszechności ustroju monarchicznego twierdził, iż ustrój państwa (w przeciwieństwie do samego stosunku władzy) nie jest zdeterminowany przez Wolę Bożą. W konsekwencji przyznawał on społeczności politycznej uprawnienie do kształtowania formy władzy, wyboru rządzącego i ewentualne wypowiedzenia mu posłuszeństwa ${ }^{12}$. Akwinata był zwolennikiem monarchii, ale na pewno nie czynił monarchy suwerenem. W epoce nowożytnej swoistą wersję teorii kontraktualistycznej zaproponował zaś jezuicki myśliciel Francisco Suárez ${ }^{13}$.

ekonomiczne: M. Chomątowska, Nauka społeczna Kościoła a gospodarka spoŁeczna, „Ekonomia Społeczna” 2013, nr 3, s. 67-79.

${ }^{10}$ Leon XIII, Encyklika „Rerum Novarum”, Rzym 1891, http://ptm.rel.pl/czytelnia/dokumenty/dokumenty-papieskie/47-leon-xiii/229-encyklika-rerumnovarum.html (dostęp: 14.05.2020 r.).

${ }^{11}$ F. Frick, hasło: Król, w: Encyklopedia biblijna, red. P. Achtemeier, red. pol. W. Chrostowski, Warszawa, 2004, s. 578.

${ }^{12}$ M. Łuszczyńska, Umowa społeczna jako fundament życia zbiorowego, „Studia Iuridica Lublinensia” 2004, nr 21, s. 43-54.

13 „Władza pochodzi od Boga w tym sensie, że człowiek jako istota społeczna potrzebuje wspólnoty ludzi, ona zaś wymaga władzy. Przyznanie jednak władzy 
Rewolucja francuska podważyła dotychczasowy ład społeczny, który można opisać, nieco upraszczając, w następujący sposób:

$$
\text { Bóg (prawo naturalne) } \rightarrow \text { Władza } \rightarrow \text { Lud }
$$

I zaproponowała nowy:

$$
\text { Lud } \rightarrow \text { Umowa społeczna (konstytucja) } \rightarrow \text { Władza }
$$

Oparcie ustroju państwa na prawie będącym pochodną ludu wydawało się zagrożeniem nie tylko dla pokoju społecznego, ale też dla samej wiary i duchowości. Biorąc pod uwagę dzieje rewolucji francuskiej i jej XIX-wiecznych reminiscencji, wydaje się zrozumiałe stanowisko Piusa IX. W Encyklice „Quanta Cura” z 1864 r. stwierdził, że wywodzenie prawa $z$ woli ludu świadczy o odejściu od „zasad zdrowego rozsądku” i skutkuje brakiem istnienia jakichkolwiek ograniczeń dla ludzkich rządz ${ }^{14}$.

Dopiero Leon XIII rozpoczął proces odchodzenia Kościoła od legitymizmu monarszego. W Encyklice „Diuturnum Illud” z 1881 r. podkreślił, że choć katolicy nie mogą się zgodzić, iż „wszelka władza

określonym jednostkom zależy od umowy wyraźnej lub milczącej. Bezpośrednio więc władza pochodzi od ludu, od całej społeczności”. S. Ziemiański, Franciszek Suarez, Kraków 2004, s. 132-133. Zob. też: Ch. Shields, F. Schwartz, hasło: Francisco Suárez, w: E. Zalta, The Stanford Encyclopedia of Philosophy (Winter 2019 Edition), https://plato.stanford.edu/entries/suarez/ (dostęp: 18.08.2020 r.); K. Chojnicka, H. Olszewski, Historia doktryn politycznych i prawnych, Poznań 2004, s. 101. Niewątpliwie przydałoby się tłumaczenie na język polski i opracowanie traktatu De legibus ac Deo legislatore, w którym jezuicki myśliciel wyłożył swoją filozofię państwa i prawa.

14, „[...] niektórzy, gardząc najbardziej oczywistymi zasadami zdrowego rozsądku i odrzucając je, ośmielają się donośnym głosem twierdzić, że wola ludu wyrażona, jak mówią, przez opinię publiczną, bądź w jakikolwiek inny sposób, stanowi najwyższe prawo. A w odniesieniu do struktury politycznej fakty dokonane przez to samo, że zostały dokonane, nabywają mocy prawa. A któż nie widzi i nie zdaje sobie sprawy, że społeczność ludzka pozbawiona więzów religii i prawdziwej sprawiedliwości zaiste nie będzie mieć żadnego innego celu, jak tylko zdobywanie i gromadzenie bogactw, i w swoich poczynaniach nie będzie się kierować żadnymi innymi zasadami, jak tylko nieokiełznaną żądzą swych wła- 
pochodzi od ludu”, to nie ma przeszkód, by „w pewnych wypadkach” osoba czy osoby piastujące władzę pochodziły $z$ wyboru. Podobnie zdaniem papieża - lud może sobie obrać dowolną formę ustroju politycznego. Wskazuje on jednak na konieczność ochrony praw nabytych ${ }^{15}$. Stanowisko Leona XIII zdaje się bliskie myśli Akwinaty i Suáreza. Nie jest tak reakcyjne jak pogląd Piusa IX, jednak przez wzmiankę o ochronie praw nabytych przejawia jeszcze pewną, umiarkowaną formę legitymizmu monarszego.

Za immanentną cechę państwa prawa uchodzi niewątpliwie Lockowsko-Monteskiuszowski podział władz. Leon XIII odniósł się do niego w Encyklice „Rerum Novarum”: „Muszą być koniecznie tacy, którzy prawa stanowią, którzy wymierzają sprawiedliwość, którzy wreszcie radą i powagą swoją wpływają na przebieg spraw, już wewnętrznych, już wojennych" ${ }^{16}$.

$\mathrm{Z}$ pontyfikatu Leona XIII warte uwagi są jeszcze dwa fragmenty $Z$ encyklik $A u$ milieu des sollicitudes i Longinqua oceani. Pierwsza z nich została skierowana do Francuzów w 1892 r., druga do bisku-

snych przyjemności i własnych korzyści?”. Pius IX, Encyklika „Quanta Cura”, https://ekai.pl/dokumenty/encyklika-quanta-cura/ (dostęp: 12.05.2020 r.)

15 „Nie dość na tym, wielu współczesnych, idąc śladem tych, którzy w wieku zeszłym przybrali miano filozofów, twierdzi, iż wszelka władza pochodzi od ludu, że przeto ci, którzy rządzą, nie posiadają jej sami ze siebie, lecz jako powierzoną im przez lud, i to $z$ tym zastrzeżeniem, że wola ludu, nadawszy im władzę, ma zawsze prawo im ją odebrać. Z nimi nie zgadzają się katolicy, którzy prawo panowania odnoszą do Boga, jako do przyrodzonego i koniecznego źródła władzy. Należy wszakże zaznaczyć w tym miejscu, że wybór tych, którzy mają rządzić państwem, może w pewnych wypadkach być pozostawiony woli i sądowi ludu i że to bynajmniej nie sprzeciwia się ani nie narusza doktryny katolickiej. Albowiem podobny wybór wskazuje jedynie panującego, a prawa panowania mu nie nadaje: nie tworzy władzy zwierzchniej, a tylko stanowi, kto ją ma wykonywać. Nie chodzi tu również o taki lub inny ustrój państwowy: nie ma powodu, aby Kościół nie uznawał zwierzchniej władzy jednego lub większej liczby ludzi, byle władza ta była sprawiedliwa i dążyła do dobra ogólnego. Dlatego z zastrzeżeniem co do praw nabytych, wolno ludowi taką sobie obrać formę rządu, jaka najwięcej odpowiada jego duchowi, zwyczajom i obyczajom”. Leon XIII, Encyklika „Diuturnum Illud”, nr 5-7, http://ptm.rel.pl/czytelnia/dokumenty/dokumenty-papieskie/47-leon-xiii/230-encyklika-diuturnum-illud. html\#pp230-1 (dostęp: 12.05.2020 r.).

${ }^{16}$ Leon XIII, Encyklika „Rerum”, Rzym 1891, nr 27. 
pów ze Stanów Zjednoczonych trzy lata później. Papież wyjaśnił, że każda forma rządów, której doświadczyła Francja w poprzedzającym encyklikę burzliwym stuleciu, jest akceptowalny ${ }^{17}$. Dalej podniósł problem nieprzychylności wobec religii ze strony ustawodawstwa francuskiego. Wskazał, że ze złym prawem nie można się zgadzać, ale należy z nim „walczyć wszystkimi legalnymi i uczciwymi środkami” ${ }^{18}$. Ten ostatni postulat ma przełomowy charakter i można go odczytać jako aprobatę wartości, jaką jest praworządność formalna. Nie można bowiem ze złym prawem walczyć per fas et nefas.

W Longinqua oceani papież akceptuje ustrój amerykański. Aprobuje fakt, że Konstytucja, rząd i bezstronne sądownictwo zapewniają wolność Kościołowi i wiernym. Można jednak zauważyć swego rodzaju tęsknotę za wsparciem przekazu wiary o brachium regale, rozumianym jako konfesyjność państwa i paternalizm związany z propagowaniem kultu katolickiego ${ }^{19}$.

\section{Praworządność a społeczne nauczanie Kościoła od poł. XX w.}

Ani pontyfikat Leona XIII, ani pontyfikaty jego następców nie pozwoliły w pełni uzgodnić stanowiska Kościoła $z$ koncepcją państwa

17 Leon XIII, Encyklika „Au milieu des sollicitudes”, Rzym 1892, nr 14, http://www.nonpossumus.eu/encykliki/Leon_XIII/au_milieu_des_sollicitudes/ /amds.php (dostęp: 18.05.2020 r.).

18 Ibidem, nr 24.

19 „[...] dzięki należne są sprawiedliwości praw panujących w Ameryce i zwyczajom dobrze ustanowionej Republiki. Bowiem Kościół u Was, w zgodzie $z$ Konstytucją i rządem Waszego narodu, nie skuty wrogimi ustawami, chroniony przeciw uciskowi przez powszechne prawa i bezstronność trybunałów, jest wolny by żyć i działać bez przeszkód. Choć wszystko to jest prawdą, jednak błędem byłoby wnioskować, że w Ameryce poszukiwać należy tego rodzaju bytności, która jest najbardziej pożądanym stanem Kościoła, czy że byłoby powszechnie prawne i odpowiednie dla państwa i Kościoła, by były one, jak w Ameryce, rozerwane i rozdzielone. To, że stan Kościoła jest u Was dobry, więcej, że cieszy się on nawet dostatnim wzrostem, w każdym wypadku przypisać należy płodności, jaką Bóg obdarzył Swój Kościół, przez którą, jeśli jedynie ludzie i okoliczności nie będą przeszkodą, rozwija się on i rozmnaża 
prawa. Kością niezgody nie były wcale aspekty formalne praworządności - świadczy o tym najwyraźniej aprobata Leona XIII dla trójpodziału władz w Rerum novarum oraz wezwanie, by ze złym prawem walczyć „legalnymi środkami” w Au milieu des sollicitudes. Problemem okazała się wolność sumienia i wyznania oraz świecki charakter państwa, a więc aspekty czysto materialne. Pokonanie tej przeszkody stało się możliwe dzięki dwóm procesom, z których jeden dotyczył świata, a drugi Kościoła.

Tragiczne doświadczenia II wojny światowej przyniosły odrodzenie iusnaturalizmu i pociągnęły za sobą upowszechnienie koncepcji praw człowieka. Jakobińska rządza walki $z$ religią, postrzegana jako „opium dla ludu”, ustąpiła miejsca gwarancji wolności sumienia i wyznania. Hasło to przestało się w końcu kojarzyć z laicyzmem rozumianym jako wrogość do religii. Międzynarodowe systemy prawa człowieka zyskały zaufanie i aprobatę Magisterium Kościoła - szczególnym wyrazem tej tendencji była Encyklika „Pacem in terris”20.

Jednocześnie myśl katolicka dostrzegła, że założenie świeckości państwa nie jest niczym zdrożnym. Jacques Maritain dowiódł, że zasadę zwierzchności Królestwa Bożego nad państwami ziemskimi można uobecnić inaczej niż na wspieraniu się ramieniem władzy doczesnej (np. poprzez karanie heretyków) ${ }^{21}$. Podobne poglądy prezentował amerykański jezuita John Courtney Murray ${ }^{22}$. Ich zapatrywania posłużyły wkrótce za podwaliny soborowej Deklaracji o wolności religijnej Dignitatis humanae ogłoszonej 7 grudnia 1965 r. Dokument ten $z$ godności osoby wyprowadza zasadę wol-

samoistnie; przyniósłby on tym obfitsze owoce, gdyby, prócz wolności, cieszył się on przychylnością prawa i patronatem władzy publicznej”. Leon XIII, Encyklika „Longinqua oceani”, Rzym 1895, nr 6, http://www.ptm.rel.pl/czytelnia/dokumenty/dokumenty-papieskie/47-leon-xiii/349-encyklika-longinqua-oceani. html (dostęp: 23.07.2020 r.).

${ }^{20}$ Jan XXIII, Encyklika „Pacem in terris”, Rzym 1963, http://ptm.rel.pl/czytelnia/dokumenty/dokumenty-papieskie/41-jan-xxiii/227-encyklika-pacemin-terris.html (dostęp: 4.08.2020 r.). Szerzej na ten temat: G. Beyer, Jan XXIII Jan Pawet II. Papieże praw człowieka, „Ethos” 2014, nr 2 (27/106), s. 92-137.

${ }^{21}$ J. Martain, Człowiek i państwo, Kraków 1993, s. 169.

${ }^{22}$ D. Góra-Szopiński, Złoty środek, s. 73-78. Tam też odesłania do artykułów Murraya. 
ności sumienia i wyznania. Jednostka, zarówno gdy realizuje swój obowiązek poszukiwania prawdy i trwania przy niej, jak i wtedy, gdy go zaniedbuje, musi pozostawać wolna od przymusu, szczególnie przymusu państwowego ${ }^{23}$. Tym samym II Sobór Watykański definitywnie rezygnuje $z$ roszczenia względem państw, by te oddawały cześć Bogu i zwalczały „fałszywe religie”. W konsekwencji jest możliwe uzgodnienie stanowiska Kościoła $z$ ustrojowymi założeniami demokratycznego państwa prawa. Wystarczy, że będzie ono szanować godność osoby ludzkiej, respektować prawa człowieka ${ }^{24}$. Sytuację tę możemy zilustrować następującym grafem:

\section{Człowiek $\rightarrow$ Lud $\rightarrow$ Umowa społeczna (konstytucja) Władza}

Z entuzjazmem do takiej, personalistycznej, wizji państwa prawa odniósł się Jan XXIII w przywołanej już wcześniej Encyklice „Pacem in Terris”. Papież zaznaczył, że tego jaki jest najbardziej właściwy ustrój państwa, nie da się rozstrzygnąc in abstracto. Wskazał jednak na znaczenie trójpodziału władz. Podkreślił, że stanowiący ustawy winni kierować się moralnością, konstytucją i dobrem wspólnym. Przedstawiciele władz wykonawczych mają dobrze znać ustawy, a decyzje wydawać zawsze zgodne z prawem i „po dokładnym zbadaniu wszelkich okoliczności”. Jan XXIII wspomniał również o prawości i bezstronności sędziów. Ponadto postawił ogólny wymóg, by ustawodawstwo zapewniało ochronę praw obywateli i stowarzyszeń $^{25}$. Wypowiedź ta stanowi najbardziej pogłębione, najdłuższe odniesienie do idei rządów prawa, jakie można odnaleźć w oficjalnych

${ }^{23}$ Deklaracja o wolności religijnej Dignitatis humanae, Rzym 1965, http:// ptm.rel.pl/czytelnia/dokumenty/dokumenty-soborowe/sobor-watykanski-ii/ /168-deklaracja-o-wolnosci-religijnej-dignitatis-humanae.html (dostęp: 3.08. 2020 r.).

${ }^{24}$ Por. J. Tischner, Prawda i godność. Wprowadzenie do wyboru pism Ernsta-Wolfganga Böckenförde, w: E-F. Böckenförde, Wolność-państwo, s. 10.

25 „Nie da się rozstrzygnąć ogólnie, jaki jest najwłaściwszy ustrój państwa [...] Niemniej jednak uważamy za zgodny z ludzką naturą taki ustrój, w którym działają trzy rodzaje władz, odpowiadające trzem głównym zadaniom władzy publicznej. W tego rodzaju państwie prawo ustala nie tylko zadania urzędników, lecz również i wzajemny stosunek obywateli i przedstawicieli władzy publicznej. 
dokumentach kościelnych. Znamienne jest, że papież zwraca uwagę zarówno na aspekt materialny praworządności, jak i na służący zabezpieczeniu tego pierwszego wymiar formalny, proceduralny.

W tym miejscu warto wskazać, iż na wartość praworządności zwrócił uwagę Sobór w Konstytucji duszpasterskiej o Kościele w świecie współczesnym Gaudium et spes: „Nic bardziej nie sprzyja odnowieniu życia politycznego na prawdziwie ludzkich zasadach, jak popieranie głębokiego poczucia sprawiedliwości i życzliwości oraz służby dobru wspólnemu, a także umacnianie podstawowych poglądów na prawdziwą naturę wspólnoty politycznej, jej cel, i na praworządność (podkreślenie: P.B.) oraz zakres władzy państwowej"26.

W personalistycznej perspektywie przyniesionej przez Maritaina, Jana XXIII i ojców soborowych zrozumiała staje się koniunkcja zawarta w cytacie ze społecznej encykliki Jana Pawła II Centesimus annus, przywołanym na początku niniejszej pracy. Wizja demokratycznego państwa prawa w społecznym nauczaniu Kościoła

To rzeczywiście zapewnia niewątpliwą ochronę obywatelom, już to dbającym o swe prawa, już to pełniącym swe obowiązki. Aby jednak taki ustrój prawno-polityczny spełniał pokładane w nim nadzieje, wymaga on $z$ natury rzeczy, aby urzędnicy spełniali swe zadania i rozwiązywali napotykane trudności przy zastosowaniu właściwych metod i środków, zgodnych zarówno $\mathrm{z}$ ich własnymi zadaniami, jak $\mathrm{z}$ warunkami aktualnie istniejącymi $\mathrm{w}$ państwie. Wymaga to ponadto, aby przy stale zmieniających się okolicznościach, prawodawcy nie lekceważyli nigdy w swej działalności ani zasad moralności, ani konstytucji państwowej, ani wymagań dobra wspólnego. Przedstawiciele władz wykonawczych powinni wydawać decyzje zawsze zgodnie $z$ prawem, posiadając dobrą znajomość ustaw oraz po dokładnym zbadaniu wszystkich okoliczności. Również sędziowie kierowani jedynie prawością, bez ulegania naciskom żadnej ze stron, winni każdemu przyznawać to, co mu się słusznie należy. Porządek rzeczy wymaga również, aby odpowiednie ustawy gwarantowały ochronę praw poszczególnych obywateli i stowarzyszeń oraz ochronę wypełniania przez nich obowiązków, i to zarówno w stosunkach między poszczególnymi obywatelami, jak [i] między obywatelami i przedstawicielami władz publicznych”. Jan XXIII, Encyklika „Pacem”, nr 67-69.

${ }^{26}$ Konstytucja dogmatyczna o Kościele w świecie współczesnym Gaudium et spes, Rzym 1965, nr 73, http://ptm.rel.pl/czytelnia/dokumenty/dokumenty-soborowe/soborwatykanski-ii/ 141-konstytucja-duszpasterska-o-kosciele-wswiecie-wspolczesnym-gaudium-et-spes.html (dostęp: 24.08.2020 r.). 
katolickiego nierozerwalnie wiąże się z prawami człowieka. Innymi słowy: wyklucza pozytywistyczną, czysto formalno-proceduralną interpretację. To godność osoby ludzkiej implikuje potrzebę istnienia mechanizmów formalnych i proceduralnych, które będą gwarantować jednostkom i ich wspólnotom ochronę przed uznaniowością oraz nadmierną ingerencją ze strony piastunów władzy. Warto przytoczyć ten cytat w całości: „Kościół docenia demokrację jako system, który zapewnia udział obywateli w decyzjach politycznych i rządzonym gwarantuje możliwość wyboru oraz kontrolowania własnych rządów, a także - kiedy należy to uczynić - zastępowania ich w sposób pokojowy innymi. Nie może zaś demokracja sprzyjać powstawaniu wąskich grup kierowniczych, które dla własnych partykularnych korzyści albo dla celów ideologicznych przywłaszczają sobie władzę w państwie.

Autentyczna demokracja możliwa jest tylko w Państwie prawnym i w oparciu o poprawną koncepcję osoby ludzkiej. Wymaga ona spełnienia koniecznych warunków, jakich wymaga promocja zarówno poszczególnych osób, przez wychowanie i formację w duchu prawdziwych ideałów, jak i "podmiotowości" społeczeństwa, przez tworzenie struktur uczestnictwa oraz współodpowiedzialności”27.

\section{Podsumowanie}

Społeczne nauczanie Kościoła opowiada się za praworządnością w państwie demokratycznym - taki jest obecnie najbardziej pożądany ustrój państwa w opinii Magisterium Kościoła ${ }^{28}$. Rządy prawa to $\mathrm{w}$ pierwszej kolejności respektowanie godności osoby ludzkiej, która zawsze ma być celem, a nie środkiem, i jest pierwotna względem zbiorowości. Żadne gwarancje formalne i instrumenty proceduralne nie są celem samym w sobie. Ich sens polega na ochronie godności poszczególnych osób, z których składa się społeczeństwo oraz dobra wspólnego przed nadużyciami grupy rządzącej. Kościół

27 Zob. przyp. gwiazdkowy.

28 D. Góra-Szopiński, Złoty środek, s. 223. 
katolicki jest więc orędownikiem niepozytywistycznej koncepcji państwa prawa.

Droga do tego stanu rzeczy nie była ani prosta, ani krótka. W XIX w. papiestwo stało na stanowisku bezkompromisowego legitymizmu monarszego. Sprzeciw wobec teorii kontraktualistycznych, na których opierała się koncepcja państwa prawa, uległ złagodzeniu w trakcie pontyfikatu Leona XIII. Odtąd mówić można o akceptacji Kościoła dla formalnego aspektu praworządności. Problemem wciąż pozostawało nieco inne rozumienie materialnych desygnatów praworządności przez autorytety kościelne i najbardziej wpływowych filozofów prawa. Uzgodnienie tych dwóch punktów widzenia stało się możliwe $z$ jeden strony dzięki powojennemu ruchowi praw człowieka, $z$ drugiej zaś dzięki akceptacji Kościoła dla wolności sumienia oraz państwa bezstronnego w kwestiach religijnych podczas II Soboru Watykańskiego.

\section{STRESZCZENIE}

Państwo prawa w obiektywie społecznego nauczania Kościoła katolickiego. Zarys problematyki

Najpierw autor krótko referuje historyczny rozwój idei rządów w granicach prawa. Następnie przechodzi do opisu oceny, $z$ jaką ta kategoria filozofii społecznej spotykała się ze strony Urzędu Nauczycielskiego Kościoła w XIX i XX w. Niechęć ustępuje akceptacji wraz z encykliką Jana XXIII Pacem in terris oraz dwoma dokumentami II Soboru Watykańskiego: deklaracją Dignitatis Humanae i konstytucją Gaudium et spes. Kościół opowiada się za poszanowaniem zasady państwa prawa, ale nie rozumie jej na sposób pozytywistyczny. Zdaniem Urzędu Nauczycielskiego w aspektach formalnych praworządności widzieć należy gwarancje służące zabezpieczeniu przyrodzonych praw osoby ludzkiej.

Słowa kluczowe: praworządność; państwo prawa; Kościół; katolicyzm; demokracja 


\section{SUMMARY \\ Rule of law and the catholic social doctrine. \\ An outline of issue}

First, the author briefly describes the historical development of the idea of supremacy of law. Then he goes on to describe the assessment with which this category of social philosophy was met by the Teaching Office of the Church in the nineteenth and twentieth centuries. Reluctance gives way to acceptance with John XXIII's Encyclical Pacem in Terris and two documents of the Second Vatican Council: Declaration Dignitatis Humanae and Constitution Gaudium et spes. The Church supports respect for the rule of law, but does not understand it in a positivist way. In the opinion of the Magisterium, formal aspects of the rule of law should be understood as guarantees protecting the inherent rights of the human person.

Keywords: rule of law; supremacy of law; church; Catholicism; democracy

\section{BIBLIOGRAFIA}

Achtemeier P. (red.), Chrostowski W. (red. wyd. pol.), Encyklopedia biblijna, Warszawa 2004.

Bator A., Helios J., Jedlecka W. (red.), Rzady prawa i europejska kultura prawna, Wrocław 2014, https: / /www.google.com/search?client=firefoxbd $\& q=r z \% C 4 \% 85 d y+$ prawa+a+eurpejska+kultura+prawna (dostęp: 18.08. 2020 r.).

Beyer G., Jan XXIII i Jan Paweł II. Papieże praw człowieka, „Ethos” 2014, nr $2(27 / 106)$.

Biernat T., Władze publiczne $w$ demokratycznym państwie prawa, Kraków 2014.

Biliński K., Żmuda M., Nauka społeczna Kościoła katolickiego od Leona XIII do Jana Pawła II. Wybór tekstów źródłowych, Torun 1997.

Boike P., Nowa redakcja katolickiego nauczania o karze śmierci - rewolucja czy drobna korekta?, „Dialogi Polityczne” 2019, nr 27.

Böckenförde E.W., Wolność - państwo - Kościót, tłum. P. Kaczorowski, Kraków 1994.

Chojnicka K., Nauka społeczna Kościoła katolickiego (zarys historii), Kraków 2001. 
Chojnicka K., Olszewski H., Historia doktryn politycznych i prawnych, Poznań 2004.

Chomątowska M., Nauka społeczna Kościoła a gospodarka społeczna, „Ekonomia Społeczna” 2013, nr 3.

Dylus A., Polityka w perspektywie etycznej i religijnej, Warszawa 2014.

Dziadzio A., Koncepcja państwa i prawa w XIX wieku - idea i rzeczywistość, „Czasopismo Prawno-Historyczne” 2005, nr 1 (57).

Gowder P., Rule of law in the real world, Cambridge 2016.

Góra-Szopiński D., Ztoty środek. Kościót wobec współczesnych wizji państwa, Toruń 2007.

Góra-Szopiński D., Katolicka nauka społeczna jako wyzwanie dla politologii, „Athenaeum” 2010, nr 24.

Grzybowski M., Tuleja P. (red.), Państwo demokratyczne, prawne i socjalne. Księga jubileuszowa dedykowana profesorowi Zbigniewowi Antoniemu Maciagowi. Tom 1, Studia konstytucyjne, Kraków 2014.

Herr T., Wprowadzenie do katolickiej nauki społecznej, tłum. A. Mosurek, Kraków 1999.

Isensee J., Demokratyczne państwo prawa i jego przyszłość, „Chrześcijaństwo - Swiat - Polityka” 2017, nr 21.

Juros H., Kościót - kultura - Europa: katolicka nauka społeczna wobec współczesności, Lublin-Warszawa 1997.

Kmieciak Z., O pojęciu rządów prawa, „Państwo i Prawo” 2016, nr 9.

Krygier M., The Rule of Law: Pasts, Presents, and Two Possible Futures, „Annual Review of Law and Social Science” 2016, nr 12.

Krzynówek-Arndt A., Państwo prawa w klasycznej tradycji zachodniej i późnej nowoczesności $w$ kontekście sporów wokół klauzuli demokratycznego państwa prawnego, „Przegląd Sejmowy” 2018, nr 3 (146).

Łuszczyńska M., Katolicka nauka społeczna - doktryna per se czy per participationem? „Studia Iurdica Lublinensia” 2012, nr 17.

Łuszczyńska M., Umowa społeczna jako fundament życia zbiorowego, „Studia Iuridica Lublinensia” 2014, nr 21.

Majka, J., Katolicka nauka społeczna. Studium historyczno-doktrynalne, Rzym-Lublin 1987.

Maritain J., Człowiek i państwo, Kraków 1993.

Nowacki J., Rządy prawa: dwa problemy, Katowice 1995.

Pietrzykowski T., Ujarzmianie Lewiatana. Szkice o idei rządów prawa, Katowice 2014.

Possenti V., Katolicka nauka społeczna wobec dziedzictwa oświecenia, tłum. Ł. Skuza, S. Pyszka, T. Żeleźnik, Kraków 2000.

Sadowski M., Państwo $w$ doktrynie Leona XIII, Wrocław 2002.

Sadowski M., Godność człowieka i dobro wspólne $w$ papieskim nauczaniu społecznym (1878-2005), Wrocław 2010, http: / /www.bibliotekacyfrowa. pl/publication/28119 (dostęp: 18.08.2020 r.). 
Schwindt D., Catholic Social Teaching: A New Synthesis (Rerum Novarum to Laudato Si'), McPherson 2015.

Sorge B., Wykłady z katolickiej nauki społecznej. Od Ewangelii do cywilizacji miłości, tłum. M. Zaręba, Kraków 2001.

Szlachta B., Wokót katolickiej myśli politycznej, Kraków 2008.

Taborowski M., Mechanizmy ochrony praworzadności państw członkowskich $w$ prawie Unii Europejskiej. Studium przebudzenia systemu ponadnarodowego, Warszawa 2019.

Tamanaha B., On the rule of law. History, Politics, Theory, Cambridge 2004.

Tarnowska A., Koncepcja nowoczesnego konstytucjonalizmu $w$ historii prawa, „Studia Iurdica Toruniensia” 2009, nr 5.

Tulejski T., Samuela Rutherforda koncepcja genezy społeczeństwa, władzy i państwa, „Studia Prawno-Ekonomiczne” 2019, nr 112.

Wróblewska I., Zasada państwa prawnego $w$ orzecznictwie Trybunału Konstytucyjnego RP, Toruń 2010.

Zalta E., The Stanford Encyclopedia of Philosophy (Winter 2019 Edition). https://plato.stanford.edu/entries/suarez/ (dostęp: 18.08.2020 r.). Ziemiański S., Franciszek Suarez, Kraków 2004. 